\title{
The Venture for Clean Batik Production: Input Analysis on Natural Dyeing in Batik Micro-Collectives in Klaten, Central Java, Indonesia
}

\author{
Purwanti Asih Anna Levi ${ }^{1}$, Arianti Ina Restiani Hunga ${ }^{2 *}$, Hotmauli Sidabalok ${ }^{3}$ \\ \{paa.levi@gmail.com; ina.hunga@uksw.edu; oelysidabalok@yahoo.com\}
}

PMLP UNIKA Soegijapranata ${ }^{1,3}$; Fakultas Interdisiplin, Universitas Kristen Satya Wacana ${ }^{2}$

\begin{abstract}
The growth of batik production rises environmental problems, especially after the application of synthetic dye. Water pollution caused by batik industries has been reported to occur in some batik centers. Besides water pollution, wastewater of the synthetic dye also contaminates paddy fields. A solution for these environmental problems is the application of clean production in the batik industry. One of the batik communities in Klaten has already applied natural dye. The community considered that natural dyed batik is an eco-friendly (clean) practice. This paper discusses the materials input on natural dyed batik practice from the perspective of clean production. The method used in this paper is a case study in order to describe the venture for clean batik production applied by Batik Putri Kawung. While the data are analyzed from the perspective of clean production.
\end{abstract}

Keywords: batik, batik tulis, batik warna alam, natural dye batik, eco-friendly batik, environment, clean production, sustainability

\section{Introduction}

Research in the batik industry based on "putting-out" system with an interdisciplinary approach conducted by Hunga [1] found that batik was a strategic but paradoxical industry. The growth of batik production has an impact on environmental damage, especially after the use of synthetic dyes. Water pollution caused by the batik industry is reported in several batik centers, especially Pekalongan, Sragen, and Sukoharjo [2]. Hunga [1] reported that batik wastewater polluted the rice fields so that although rice appeared to be growing well, no grain was produced. Initially, the government paid little attention to this problem because the wastewater was only in small volumes or because batik production was only a micro-small business [1]. However, due to the increasing intensity of pollution the government is making efforts to overcome this problem by building a communal wastewater treatment plant. However, the volume of the wastewater remains overloaded, therefore some batik industries will always dump their wastewater into rivers, which leads to groundwater pollution.

Lack of innovation and technology in developing environmentally friendly batik causes environmental problems [2]. The Ministry of Environment of the Republic of Indonesia emphasizes that batik industry is one of the contributors to the worst river pollution in Indonesia. Pollution from batik production comes from the excessive use of wax, synthetic dyes and bleaching agents. Every year, the batik industry produces the highest $\mathrm{CO} 2$ emissions compared to other SMEs, in addition to the highest use of fuel, water and excessive electricity. This serious problem is exacerbated by the batik production process that is carried out at home and around the homes of home-based batik workers in a "putting-out" system production mode. Batik production waste has a negative effect on batik family members, especially women, children and also the environment. Therefore, batik has a negative image because the production process is not environmentally friendly and produces wastewater that endangers the environment and human life [3].

Many batik factories operate with excessive use of water, wax, synthetic dyes and bleaching agents which are harmful to the community and the environment. In addition, many batik workers do not have adequate equipment when handling hazardous substances. Carcinogenic waste water from batik production often discharged without prior treatment from the batik factory directly into the river. This general practice exacerbates the problem of river pollution which is detrimental to the health and livelihoods of thousands of local residents [3].

One solution to those environmental problems is the application of clean production in the batik industry. The clean batik initiative implemented by EKONID in 2010-2013 was supported by European Union funding. The target of this program is 500 batik industries in 6 (six) provinces. The application of natural dyes is one of the programs introduced by EKONID to the batik business in Indonesia which aims to reduce the use of 
energy and natural resources. However, the facts show that this program is not sustainable and do not make significant changes in the practice of batik production towards clean batik (environmentally friendly batik). This also poses a threat to the recognition of batik in the market which pays attention to the principle of clean production. One of the batik communities in the Klaten batik cluster has been producing natural dyed batik. That batik communities claim that their product is environmentally friendly batik. However, it needs to be investigated whether it is true that the practice of natural dyed batik is really an application of environmentally friendly batik. The purpose of this paper is to describe the practice of materials input on natural dyed batik production from the perspective of clean production. The significance of this paper is as input for developing environmentally friendly batik based on the perspective of clean production.

\section{Methods}

This research was conducted in the village of Jarum, Bayat Sub-district of Klaten Regency from December 2017 until April 2019. The village of Jarum was chosen as a research location because of 2 considerations, i.e.: 1) some of the batik industries in this cluster produce natural dyed batik which is claimed as eco-friendly batik, and 2) some of the batik industries in this cluster have gotten training of clean production from EKONID in 2010-2013.

This research is a qualitative research with case study method. The subject of this research is the batik home industry that produces natural dyed batik namely Batik Putri Kawung. The micro collectives have 20 members, which each member has a specific skill. The group's members work together to form a chain of production.

The collected data are primary and secondary data. The primary data were collected through structured interview, in-depth interviews, observations, and documentation of activities in the form of photographs and audio. Secondary data is obtained from the literature. Data are analyzed using descriptive qualitative analysis.

\section{Results and Discussion}

\subsection{Natural Dyed Batik and Clean Production}

The 1992 Earth Summit concluded that global environmental degradation had risen as a result of an unsustainable pattern of consumption and production and this finding raised the important issue of sustainable production. In Indonesia, the policy of implementing sustainable production and consumption was launched in 2013 by The Ministry of Environment of Republic of Indonesia, which encouraged businesses to move to clean production. It was suggested that businesses both big and small, including Small and Medium Enterprises (SMEs), should implement this policy to ensure clean production.

The definition of clean production according to United Nations Environmental Program is an integrated environmental impact prevention strategy that is applied continuously to processes, products, services, to improve overall efficiency and reduce risks to people and the environment. While the purpose of clean production according to The Ministry of Environment Republic of Indonesia is to: a) Increase the efficiency of the use of natural resources, b) Prevent environmental pollution, and c) Reduce waste generation at the source so as to minimize risks to human health and safety as well as environmental damage. Moreover, the pattern of clean production approach in preventing, improving efficiency, and minimizing waste, that is with strategy rethink, reduce, reuse, recycle, recovery/reclaim, replant and values revitalization. Clean production practices include the application of technologies that can prevent or reduce waste generation, including soft technology to hard technology. The clean production actions according to United State Environmental Protection Agency in Sulaeman [4] and Nurdalia [5] include product change and process change which include: a) change of material input, b) change of technology, c) change of operating practices, and d) change of product.

In batik industry, clean production was introduced by the German Indonesian Chamber of Commerce (EKONID) through the implementation of the Clean Batik Initiative program in 2010-2013 supported by EU funding. This program was designed to initiate the implementation of sustainable production and the concept of sustainable consumption set out in the Sustainable Development Goals to batik industries. The application of natural dye is one of the programs introduced by EKONID to batik businesses in Indonesia, alongside other programs aimed to reduce the use of energy and natural resources [3]. Although not all batik businesses are yet moving towards a production using natural dye, this programme has made an important contribution towards initiating clean production in the Indonesian batik industry. 
The batik community Putri Kawung in the village of Jarum Klaten has been producing natural dyed batik since 2010. Natural dyed batik is considered as an eco-friendly batik. This image has strongly influenced the people of the village and gradually general mindset that natural dyed batik is eco-friendly has developed among them [6]. However, the explanation of the application of the natural dyed batik from the clean production perspective has not been explored yet. Hence, it will be discussed in this paper. This figure 1 describes the diagram of analysis from the clean production perspective. The authors describe only a part of all parts of natural dyed practiced by Batik Putri Kawung. This paper only discusses the practices of the materials input (raw materials, supporting materials, energy, water and electricity) (green box).

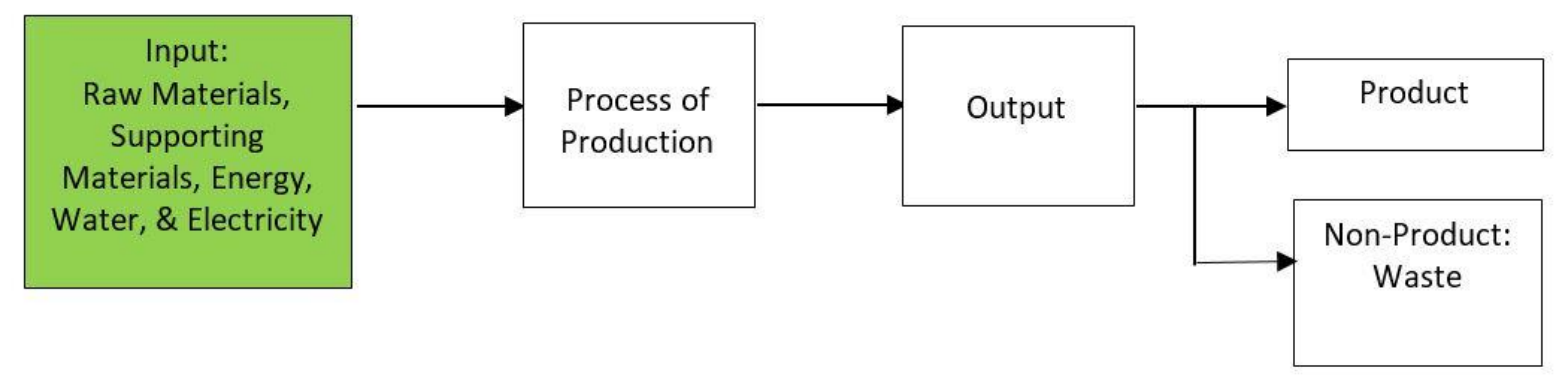

(Source: Nurdalia, 2006) 


\subsection{Results of Practice of Materials Input in Natural Dye Batik}

\begin{tabular}{|c|c|c|c|c|}
\hline \multirow{2}{*}{$\begin{array}{l}\text { MATERIALS } \\
\text { INPUT }\end{array}$} & \multirow[t]{2}{*}{ BATIK MAKERS' PRACTICE } & \multicolumn{3}{|c|}{ CLEAN PRODUCTION PERSPECTIVE } \\
\hline & & STRATEGIES & ACTIONS & ANALYSIS \\
\hline Cloth & 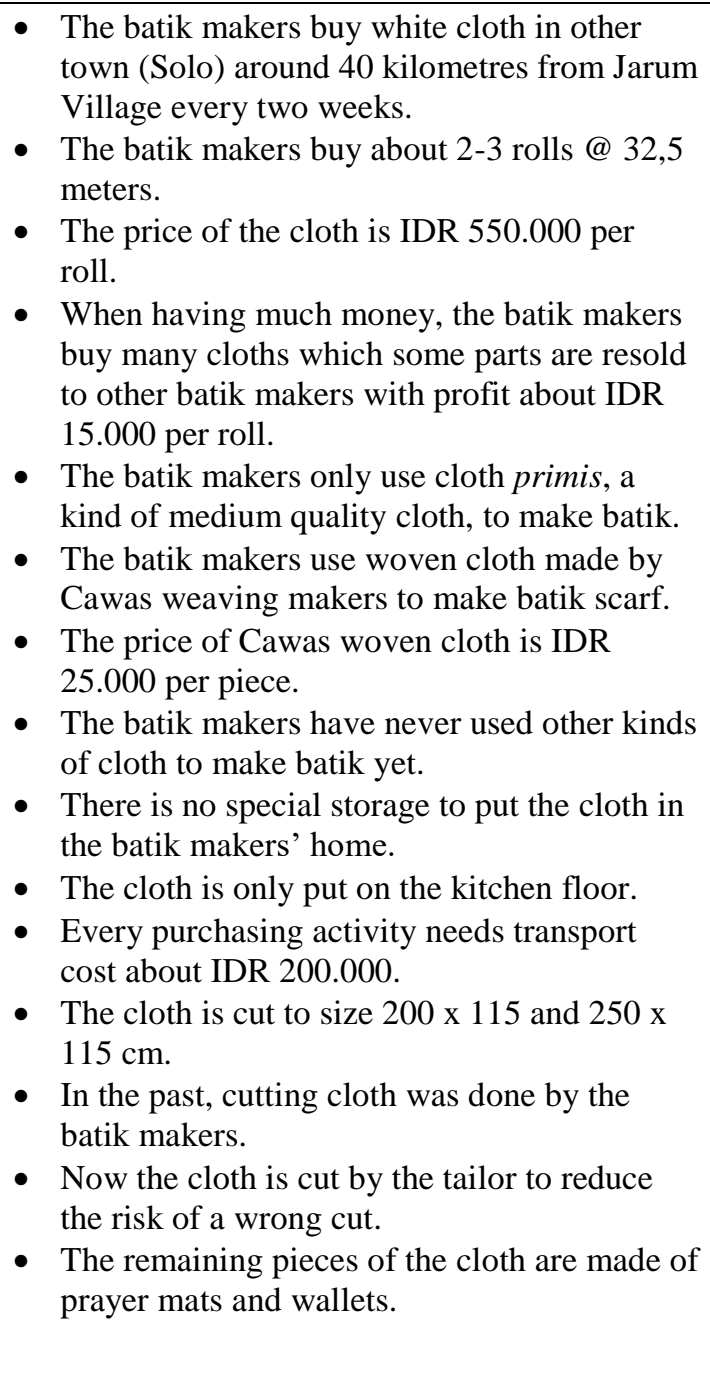 & $\begin{array}{l}\text { - Re-think: the batik makers } \\
\text { think of an efficient way of } \\
\text { working. } \\
\text { - Reduce: the purchasing in } \\
\text { a big scale when the batik } \\
\text { makers have much money } \\
\text { reduces the frequency of } \\
\text { purchasing that implies to } \\
\text { the reduction of transport } \\
\text { costs and carbon emission. } \\
\text { Reduce: to reduce the risk } \\
\text { of wrong cutting, the batik } \\
\text { makers give the job of } \\
\text { cutting cloth to a } \\
\text { professional person. } \\
\text { Reduce: the batik makers } \\
\text { reduce the waste of the } \\
\text { remaining pieces of the } \\
\text { cloth by using it to become } \\
\text { useful products. } \\
\text { Reclaim/recovery: the } \\
\text { batik makers pick up the } \\
\text { remaining pieces of cloth } \\
\text { to make prayer mats and } \\
\text { wallets. }\end{array}$ & $\begin{array}{l}\text { Change of operational } \\
\text { practice: When the batik } \\
\text { makers have much } \\
\text { money, they change the } \\
\text { practice of cloth } \\
\text { purchasing so that they } \\
\text { can resell the cloth to } \\
\text { other batik makers and } \\
\text { get profit from it that can } \\
\text { be used to cover transport } \\
\text { costs. } \\
\text { Change of operational } \\
\text { practice: the job of } \\
\text { cutting cloth that in the } \\
\text { past was done by the } \\
\text { batik makers often at risk } \\
\text { of cutting is now } \\
\text { transferred to the } \\
\text { professional tailor to } \\
\text { reduce the risk of cutting. }\end{array}$ & $\begin{array}{l}\text { Planet } \\
\text { - The cloth purchasing to other town } \\
\text { implies to high carbon emission. } \\
\text { - High carbon emission has negative } \\
\text { impacts to environment. } \\
\text { - Waste from the remaining pieces of } \\
\text { cloth is reduced. } \\
\text { People } \\
\text { - High carbon emission has negative } \\
\text { impacts to the batik makers' health. } \\
\text { - By transferring the job of cutting cloth } \\
\text { to professional tailors, the batik makers } \\
\text { can use their time and energy to do } \\
\text { other works so that it is efficient in } \\
\text { terms of time and energy. } \\
\text { Profit } \\
\text { - The high purchasing frequency implies } \\
\text { to increase the use of energy, time, and } \\
\text { costs. } \\
\text { - If the batik makers have no alternatives } \\
\text { of cloth it will have high risk for the } \\
\text { production sustainability whenever } \\
\text { there is a scarcity of cloth supply. } \\
\text { - The cloth purchasing in a big scale can } \\
\text { reduce the purchasing frequency that } \\
\text { implies to the reduction the use of } \\
\text { energy, time, and costs. } \\
\text { - The cloth that is not keep well and is } \\
\text { only put on the kitchen floor relatively } \\
\text { has high risk of damage. } \\
\text { can cover the transport costs. } \\
\text { of cloth have a sale value. }\end{array}$ \\
\hline
\end{tabular}




\begin{tabular}{|c|c|c|c|c|}
\hline & & & & $\begin{array}{l}\text { The job of cutting cloth that is } \\
\text { transferred to a professional tailor } \\
\text { reduces the risk of wrong cutting, so as } \\
\text { to minimize the cost of purchasing } \\
\text { cloth. }\end{array}$ \\
\hline Wax & $\begin{array}{l}\text { - The batik makers buy wax in other town } \\
\text { (Solo) around } 40 \text { kilometres from Jarum } \\
\text { Village every two weeks. } \\
\text { - The batik maker buys about } 25-30 \mathrm{~kg} \text {. } \\
\text { - The price of the wax is IDR } 30.000 \text { per kg. } \\
\text { - When having much money, the batik makers } \\
\text { buy many waxes which some parts are resold } \\
\text { to other batik makers with profit about IDR } \\
\text { 3.000 per kg. } \\
\text { - The batik makers buy } 2 \text { kinds of wax, i.e. } \\
\text { klowong wax (for first batik job/nglowongi) } \\
\text { and tembokan wax (for second batik } \\
\text { job/nemboki). } \\
\text { - The price of klowong wax, which has light } \\
\text { brown colour, is IDR } 30.000 / \mathrm{kg} \text {. } \\
\text { - The price of tembokan wax, which has dark } \\
\text { brown colour, is IDR } 28.000 / \mathrm{kg} \text {. } \\
\text { - The wax is put on the floor of the batik } \\
\text { makers' workshop side by side with the } \\
\text { natural dye material. } \\
\text { - The batik makers collect droplets of wax } \\
\text { from pans and canting with a sheet of zinc. } \\
\text { - The batik makers hold droplets of wax from } \\
\text { the canting with a cloth placed in the batik } \\
\text { makers' laps. }\end{array}$ & $\begin{array}{l}\text { Re-think: the batik makers } \\
\text { think of an efficient way of } \\
\text { working. } \\
\text { - Reduce: the purchasing in } \\
\text { a big scale when the batik } \\
\text { makers have much money } \\
\text { reduces the frequency of } \\
\text { purchasing that implies to } \\
\text { the reduction of transport } \\
\text { costs and carbon emission. } \\
\text { Reduce: the batik } \\
\text { makers reduce wax waste } \\
\text { by storing droplets of wax } \\
\text { from pans and canting with } \\
\text { a sheet of zinc. } \\
\text { Reclaim/recovery: The } \\
\text { batik makers take the wax } \\
\text { waste that comes from } \\
\text { spills from the pan and the } \\
\text { canting to be used to make } \\
\text { batik again. }\end{array}$ & $\begin{array}{l}\text { Change of operational } \\
\text { practice: When the batik } \\
\text { makers have much } \\
\text { money, they change the } \\
\text { practice of wax } \\
\text { purchasing so that they } \\
\text { can resold the wax to } \\
\text { other batik makers and } \\
\text { get profit from it that can } \\
\text { be used to cover transport } \\
\text { costs. }\end{array}$ & $\begin{array}{l}\text { Planet } \\
\text { - The wax purchasing to other town } \\
\text { implies to high carbon emission. } \\
\text { - High carbon emission has negative } \\
\text { impacts to environment. } \\
\text { - The batik makers pick up waste wax } \\
\text { and reuse it to make batik so that it can } \\
\text { reduce the wax waste. } \\
\text { People } \\
\text { - High carbon emission has negative } \\
\text { impacts to the batik maker's health. } \\
\text { Profit } \\
\text { - The high purchasing frequency implies } \\
\text { to increase the use of energy, time, and } \\
\text { cost. } \\
\text { - The wax purchasing in a big scale can } \\
\text { reduce the purchasing frequency that } \\
\text { implies to the reduction the use of } \\
\text { energy, time, and cost. } \\
\text { - The wax that is not keep well and is } \\
\text { only put on the kitchen floor relatively } \\
\text { has high risk of damage. } \\
\text { - Batik makers pick up wax waste and } \\
\text { reuse it to make batik so that it can } \\
\text { reduce the cost of wax purchasing. } \\
\text { - The profit gotten from reselling wax } \\
\text { can cover the transport cost. }\end{array}$ \\
\hline $\begin{array}{l}\text { Natural dye } \\
\text { materials }\end{array}$ & $\begin{array}{l}\text { The batik makers buy some natural dye } \\
\text { materials in other town (Solo) around } 40 \\
\text { kilometres from Jarum Village every two } \\
\text { weeks. } \\
\text { - Indigo is bought from an indigo seller } \\
\text { coming from Ambarawa. }\end{array}$ & $\begin{array}{l}\text { - Re-think: the batik makers } \\
\text { think of an efficient way of } \\
\text { working. } \\
\text { - Re-think: the batik makers } \\
\text { re-think to use eco-friendly } \\
\text { materials. }\end{array}$ & $\begin{array}{l}\text { - Change of material input: } \\
\text { the batik maker changes } \\
\text { the material input from } \\
\text { synthetic material to } \\
\text { natural material. } \\
\text { - Change of operational }\end{array}$ & $\begin{array}{l}\text { Planet } \\
\text { - The wax purchasing to other town } \\
\text { implies to high carbon emission. } \\
\text { - High carbon emission has negative } \\
\text { impacts to environment. } \\
\text { People }\end{array}$ \\
\hline
\end{tabular}




\begin{tabular}{|c|c|c|c|c|}
\hline & $\begin{array}{l}\text { - The batik makers buy about } 10-15 \mathrm{~kg} \text { per } \\
\text { material. } \\
\text { - The price of natural dye materials is various. } \\
\text { - When having much money, the batik makers } \\
\text { buy many natural dye materials which some } \\
\text { parts are resold to other batik makers with } \\
\text { profit about IDR } 2.000 \text { - } 3.000 \text { per kg. } \\
\text { - The batik makers use natural dye materials } \\
\text { coming from tree trunks, tree bark, fruit and } \\
\text { leaves. } \\
\text { - All of natural dye materials are bought, none } \\
\text { which is plant by the batik maker. } \\
\text { - The batik makers use natural fixation material } \\
\text { (lime) and synthetic materials (alum and } \\
\text { copperas). }\end{array}$ & $\begin{array}{l}\text { Replace: the batik makers } \\
\text { replace the synthetic dye } \\
\text { materials into natural dye } \\
\text { materials. } \\
\text { - Reduce: the purchasing in a } \\
\text { big scale when the batik } \\
\text { maker has much money } \\
\text { reduces the frequency of } \\
\text { purchasing that implies to } \\
\text { the reduction of transport } \\
\text { cost and carbon emission. }\end{array}$ & $\begin{array}{l}\text { practice: When the batik } \\
\text { maker has much money, } \\
\text { she changes the practice } \\
\text { of wax purchasing so that } \\
\text { she can resold the wax to } \\
\text { other batik makers and } \\
\text { get profit from it that can } \\
\text { be used to cover transport } \\
\text { cost. }\end{array}$ & $\begin{array}{l}\text { - High carbon emission has negative } \\
\text { impacts to the batik maker's health. } \\
\text { - The batik makers need to replant the } \\
\text { natural dye material to revitalize the } \\
\text { knowledge of natural dye materials. } \\
\text { - The batik makers need to explore } \\
\text { natural dye coming from plants in } \\
\text { environment to enrich their knowledge } \\
\text { about natural dye. } \\
\text { Profit } \\
\text { - The high purchasing frequency implies } \\
\text { to increase the use of energy, time, and } \\
\text { cost. } \\
\text { The natural dye materials purchasing in } \\
\text { a big scale can reduce the purchasing } \\
\text { frequency that implies to the reduction } \\
\text { the use of energy, time, and cost. } \\
\text { The profit gotten from reselling natural } \\
\text { dye materials can cover the transport } \\
\text { cost. }\end{array}$ \\
\hline Water & $\begin{array}{l}\text { - In the past, the batik makers took water from } \\
\text { neighbour's dug well by drawing water. } \\
\text { - Now the batik makers take water from her } \\
\text { own artesian well. } \\
\text { - Costs for making well is IDR } 35.000 .000 \text {. } \\
\text { - The artesian well is located on the left front } \\
\text { of the batik workshop. } \\
\text { - The depth of the artesian well is } 30 \text { meters. } \\
\text { - The artesian well water is clearer than dug } \\
\text { well water. } \\
\text { - The use of water for production activities is } \\
\text { not separated from the use for household's } \\
\text { activities. } \\
\text { - The batik makers use an automatic water } \\
\text { pump. } \\
\text { - The batik makers have a water reservoir with } \\
\text { a capacity of } 550 \text { litres. } \\
\text { - There are } 2 \text { water tanks with size @ } 75 \text { x } 100\end{array}$ & $\begin{array}{l}\text { - Re-think: the batik makers } \\
\text { re-think to have her own } \\
\text { well. } \\
\text { - Replace: the batik makers } \\
\text { replace the water resource } \\
\text { from her neighbour's dug } \\
\text { well to her own artesian } \\
\text { well. } \\
\text { - Reduce: taking water from } \\
\text { their own well reduces } \\
\text { time, distance and human } \\
\text { energy. } \\
\text { - Reduce: supplying water } \\
\text { with an automatic water } \\
\text { pump reduces time and } \\
\text { human energy. }\end{array}$ & $\begin{array}{l}\text { Change of technology: the } \\
\text { batik maker changes the } \\
\text { way of taking water from } \\
\text { the manual method } \\
\text { (draw) to the use of an } \\
\text { automatic electricity } \\
\text { water pumping machine. }\end{array}$ & $\begin{array}{l}\text { Planet } \\
\text { - It is difficult to calculate the exact } \\
\text { amount of water used for batik } \\
\text { production because when washing batik } \\
\text { cloth constantly open the faucet, even } \\
\text { though the water in the washing tank is } \\
\text { full. } \\
\text { - Uncontrolled use of water negatively } \\
\text { impacts the sustainability of water } \\
\text { resources. } \\
\text { People } \\
\text { - Better water quality has a positive } \\
\text { impact on batik makers' health. } \\
\text { - The batik makers now have more } \\
\text { energy and time after they no longer } \\
\text { draw water manually but use automatic } \\
\text { water pumps, so the batik workers' } \\
\text { energy and time can be used to do other }\end{array}$ \\
\hline
\end{tabular}




\begin{tabular}{|c|c|c|c|c|}
\hline & $\begin{array}{l}\text { x } 100 \mathrm{~cm} \text { as a place to wash batik cloth that } \\
\text { has been boiled to release wax. } \\
\text { When washing batik cloth, the batik makers } \\
\text { constantly open the faucet, even though the } \\
\text { water in the washing tank is full, with the } \\
\text { reason that batik cloth is quickly cleaned. }\end{array}$ & & & $\begin{array}{l}\text { work. } \\
\text { Profit } \\
\text { - After owning her own well, water } \\
\text { supply is more efficient with time, } \\
\text { distance and energy than before owning } \\
\text { her own well. } \\
\text { - Water supply is more secure. }\end{array}$ \\
\hline Energy & $\begin{array}{l}\text { - Some batik makers use kerosene stoves to } \\
\text { heat wax. } \\
\text { - The price of kerosene is IDR } 13.000 / \text { litre. } \\
\text { - When there is no kerosene supply, the batik } \\
\text { makers replace it with diesel. } \\
\text { - The price of diesel is IDR } 11.000 / \text { litre. } \\
\text { - One litre of kerosene / diesel can be used for } \\
\text { a week. } \\
\text { - Diesel emits smoke that is more concentrated } \\
\text { and causes itching in the oesophagus and sore } \\
\text { in the eyes. } \\
\text { - The batik makers buy kerosene and diesel at } \\
\text { the nearest store. } \\
\text { - Some batik makers use firewood to heat the } \\
\text { wax. } \\
\text { - The batik makers also use firewood to boil } \\
\text { the natural dye material and release wax / } \\
\text { nglorod. } \\
\text { - The batik makers buy firewood from their } \\
\text { neighbours. } \\
\text { - Every } 3 \text { months the batik makers buy a truck } \\
\text { of firewood. } \\
\text { - A truck consists of } 60 \text { bunches of firewood. } \\
\text { - The price of a truck of firewood is IDR } \\
750.000 \text {. } \\
\text { - If the batik makers buy firewood at retail, the } \\
\text { price is IDR } 13,000 \text { per bunch. } \\
\text { Trom boil a drum of water used to release wax } \\
\text { bunches of firewood. }\end{array}$ & $\begin{array}{l}\text { Reduce: the batik makers } \\
\text { buy kerosene batik buy } \\
\text { kerosene at the nearest } \\
\text { store, so it is efficient in } \\
\text { terms of distance, time and } \\
\text { costs. } \\
\text { - Reduce: the use of } \\
\text { firewood (biomass) reduces } \\
\text { the use of non-renewable } \\
\text { fuels. }\end{array}$ & $\begin{array}{l}\text { - Change of materials } \\
\text { input: The batik makers } \\
\text { change some of the } \\
\text { materials input by } \\
\text { replacing non-renewable } \\
\text { fuels with renewable } \\
\text { biomass fuels. }\end{array}$ & $\begin{array}{l}\text { Planet } \\
\text { - Kerosene and diesel are not renewable } \\
\text { fuels. } \\
\text { - The use of non-renewable fuels has a } \\
\text { negative impact on the sustainability of } \\
\text { energy resources. } \\
\text { - High carbon emissions emitted by } \\
\text { kerosene and diesel have a negative } \\
\text { impact on the environment. } \\
\text { People } \\
\text { - High carbon emissions emitted by } \\
\text { kerosene and diesel have a negative } \\
\text { impact on the batik makers' health. } \\
\text { - Smoke emitted by burning kerosene and } \\
\text { diesel fuel causes disruption to } \\
\text { respiratory and eyes health. } \\
\text { Profit } \\
\text { - The batik makers buy kerosene batik } \\
\text { buy kerosene at the nearest store, so it is } \\
\text { efficient in terms of distance, time and } \\
\text { costs. } \\
\text { - The price of firewood is relatively } \\
\text { cheaper than fuel oil. }\end{array}$ \\
\hline
\end{tabular}




\begin{tabular}{|c|c|c|c|c|}
\hline Electricity & $\begin{array}{l}\text { - Electricity is used for the water pump and } \\
\text { lighting lamps. } \\
\text { - The use of electricity for production activities } \\
\text { is not separated from the use for household } \\
\text { activities. } \\
\text { - The batik makers subscribe to } 900 \text {-watt } \\
\text { electricity. } \\
\text { - Every month batik makers pay an electricity } \\
\text { fee of IDR 70,000. }\end{array}$ & - None. & - None. & $\begin{array}{l}\text { Profit } \\
\text { - It is difficult to calculate the exact costs } \\
\text { of electricity used for batik production } \\
\text { activities. }\end{array}$ \\
\hline
\end{tabular}




\subsection{Discussion}

The authors divide this sub-chapter into 6 parts: 1) Reflection of cloth input, 2) Reflection of wax input, 3) Reflection of natural dye materials input, 4) Reflection of water input, 5) Reflection of energy input, and 6) Reflection of electricity input.

Since the Batik Putri Kawung micro collectives have to buy cloth in other town that is about 40 kilometres from their home every two weeks, they practice some efforts for efficiency. Based on the clean batik production perspective, the Batik Putri Kawung micro collectives already practice a strategy of clean production by buying cloth in a big scale when they have much money. This strategy can reduce the frequency of cloth purchasing that implies to the reduction of time, energy, costs, and carbon emission. When they have much money, they change the practice of cloth purchasing by buying cloth in a big scale so that they can resell the cloth to other batik makers. The profit can be used to cover their transport costs. The batik makers in this micro collective only use cloth primis, a kind of medium quality cloth, to make batik. While for making batik scarf, they only use woven cloth made by Cawas weaving makers. The batik makers have never used other kinds of cloth to make batik yet. If the batik makers have no alternatives of cloth it will have high risk for the production sustainability whenever there is a scarcity of cloth supply. The cloth that will be made batik, firstly is cut to size $200 \times 115 \mathrm{~cm}$ and $250 \times 115 \mathrm{~cm}$. In the past, cutting cloth was done by the batik makers. Then they change the operational practice by transferred the job of cutting cloth to a professional tailor in order to reduce the risk of a wrong cut. This strategy can reduce the waste cloth causing by a wrong cut. To reduce the waste cloth, the remaining pieces of the cloth are made of prayer mats and wallets. By transferring the job of cutting cloth to professional tailors, the batik makers can use their time and energy to do other works so that it is efficient in terms of time and energy. The strategy and action of clean production that are practiced by the micro collectives bring benefits to planet (environment), people, and profit. But they have a weakness in cloth storage, where they have no special storage to put the cloth. The cloth is not keep well and only put on the kitchen floor, so that it relatively has high risk of damage.

The Batik Putri Kawung micro collectives have also to buy wax in other town that is about 40 kilometres from their home every two weeks. They have an efficient strategy to reduce costs. When they have much money, they buy wax in a big scale. This strategy can reduce the frequency of cloth purchasing that implies to the reduction of time, energy, costs, and carbon emission. When they have much money, they also change the operational practice of wax purchasing by buying wax in a big scale so that they can resell the wax to other batik makers. The profit can be used to cover their transport costs. During applying wax to the cloth, the batik makers collect droplets of wax from pans and canting with a sheet of zinc. The batik makers also hold droplets of wax from the canting with a cloth placed in their laps and then they reclaim that wax to make batik again. The strategy and action of clean production that are practiced by the micro collectives bring benefits to planet (environment), people, and profit.

To buy natural dye materials, every two weeks the Batik Putri Kawung micro collectives have also go to other town that is about 40 kilometres from their home. For efficiency, when they have much money, they buy the natural dye materials in a big scale which some of them can be sold to other batik makers. The gotten profit can cover their transport costs. The micro collectives are also re-thinking to replace the dye materials from synthetic dye materials into natural dye materials that are environmentally friendly. This clean production action benefits the environment and human health. The economic advantage is obtained indirectly that the batik product can enter the export market which requires the use of non-carcinogenic dye. However, there is no replant strategy to ensure the sustainability of natural dye plants because the natural dye plants are not available in the local area and must be bought from other town. If they plant their own natural dye, they can increase the economic value of local natural resources. Besides, they can enrich their knowledge of natural dye by exploring plants around their environment that can be used as natural dye, because each part of the plant can give different colours. The colour variations are unlimited and the source of natural dye is available in their place, cheap and environmentally friendly.

In the past, the Batik Putri Kawung micro collectives took water from neighbour's dug well by drawing water. The batik makers re-think to have their own well, so that they can reduce time, distance and human energy used to take water. Now the batik makers take water from their own artesian well. The artesian well water is clearer than dug well water. By owning a well, their water supply is more secure. They also change the way of taking water from the manual method (draw) to the use of an automatic electricity water pumping machine. The batik makers use an automatic electric pump to drain water to the 550-litre water reservoir. After using the automatic electricity water pumping machine, they now have more energy than before, so their energy and time can be used to do other work. This is in line with Sezen \& Çankaya who said that in order to achieve sustainable development, enterprises must redesign products and adapt new technology for processes [7]. But 
unfortunately, in this micro collective the use of water for production activities is not separated from the use for household's activities. Besides, there is a bad practice of water waste that is done by the batik makers. During washing batik cloth, they constantly open the faucet, even though the water in the washing tank is full, with the reason that the batik cloth is quickly cleaned. These bad practices cause difficulties in calculating the exact amount of water used for batik production activities. This uncontrolled use of water also negatively impacts the sustainability of water resources.

In this micro collective, some batik makers use kerosene stoves to heat wax and the others use firewood. The batik makers buy kerosene and firewood at the nearest store, so it is efficient in terms of distance, time and costs. When there is no kerosene supply, the batik makers replace it with diesel that is cheaper than kerosene. But diesel emits smoke that is more concentrated and causes itching in the oesophagus and sore in the eyes. Kerosene and diesel are non-renewable fuels. The use of non-renewable fuels has a negative impact on the sustainability of energy resources. High carbon emissions emitted by kerosene and diesel have a negative impact on the environment and the batik makers' health. Smoke emitted by burning kerosene and diesel fuel causes disruption to respiratory and eyes health. Furthermore, besides using firewood to heat wax, the batik makers also use it to boil water that is used to release wax from the batik cloth after colouring process. It will be better if they use electricity stove to heat wax in batik jobs and use gas stove to boil water for removing wax (nglorod) activity. On the other hand, the use of firewood (biomass) reduces the use of non-renewable fuels. The benefits of using firewood are: a) easily to find and b) the price of firewood is relatively cheaper than fuel oil. Compared to buying, if batik makers plant wood that can be used as an energy source, it will be more profitable. Wood that can be a source of energy is wood from species of species with fast growth, dense branching, high specific gravity, high increment, easy to grow in a variety of growing conditions, sprout quickly after pruning, has a high calorific value, and easily propagated. Planting can be done in the area around the batik makers' settlement. The disadvantage is that firewood causes carbon emissions, which creates a conflict with policies to reduce carbon emissions.

The Batik Putri Kawung micro collectives use electricity for energy source for automatic water pump and lighting lamps. The use of electricity for production activities is not separated from the use for household activities. For the reason, it is difficult to calculate the exact costs of electricity used for batik production activities. The batik makers subscribe to 900 -watt electricity. Every month batik makers pay an electricity fee of IDR 70,000. It will be good if they use electricity not only for automatic water pump and lighting lamps only but also for electrical stove to heat wax in batik jobs.

\section{Conclusion}

Based on input analysis from the perspective of clean production, it can be concluded that Batik Putri Kawung micro collectives already practiced several clean production strategies and actions in the input of raw materials, supporting materials, water and energy. They are: a) for efficiency the batik makers buy cloth, wax, and natural dye materials in a big scale when they have much money; b) when they buy cloth, wax, and natural dye materials in a big scale, furthermore they can resell that materials to other batik makers. The profit can be used to cover their transport costs; b) they change the operational practice by transferred the job of cutting cloth to a professional tailor in order to reduce the risk of a wrong cut. By transferring the job of cutting cloth to professional tailors, the batik makers can use their time and energy to do other works so that it is efficient in terms of time and energy; c) to reduce the waste cloth, the remaining pieces of the cloth are made of prayer mats and wallets, d) during applying wax on the cloth, the batik makers collect droplets of wax from pans and canting with a sinc. And they also hold droplets of wax from the canting with a cloth placed in their laps and then they reclaim that wax to make batik again; e) the micro collectives are also re-thinking to replace the dye materials from synthetic dye materials into natural dye materials that are environmentally friendly; and f) the batik makers re-think to have their own well, so that they can reduce time, distance and human energy used to take water. By owning a well, their water supply is more secure.

From the perspective of clean production, the weaknesses of the practices of input materials in this micro collective are: a) the batik makers have never used other kinds of cloth to make batik yet. If the batik makers have no alternatives of cloth it will have high risk for the production sustainability whenever there is a scarcity of cloth supply; b) where they have no special storage to store the cloth. The cloth is not keep well and only put on the kitchen floor, so that it relatively has high risk of damage; c) there is no replant strategy to ensure the sustainability of natural dye plants because the natural dye plants are not available in the local area and must be bought from other town. If they plant their own natural dye, they can increase the economic value of local natural resources; d) they are not separate the use of water for production activities from household's activities; e) during washing batik cloth, they constantly open the faucet, even though the water in the washing tank is full, with the reason that the batik cloth is quickly cleaned; and f) they are still use non-renewable energy 
to heat wax and to boil water for removing wax (nglorod) activity. It will be better to use electrical stove for heating wax in batik jobs than kerosene stove and firewood.

The authors have some recommendations for the batik makers, i.e. a) try to use other alternative kinds of cloth, for example silk to sustain production whenever there is a scarcity of one kind of cloths supply; b) make a special storage to store the cloth so that it can keep well; c) try to plant many kinds of trees to ensure the sustainability of natural dye plants because the natural dye plants are not available in the local area and must be bought from other town. If they plant their own natural dye, they can increase the economic value of local natural resources; d) separate the use of water for production activities from household's activities; e) during washing batik cloth, it is good to close the faucet when the water in the washing tank is full to save water; and f) use electrical stove to heat wax and gas stove to boil water for removing wax (nglorod) activity to reduce the use of non-renewable energy.

\section{References}

[1] A. I. R. Hunga, “Ancaman Kerusakan Ekologis Produksi Batik Rumahan: Narasa Perlindungan Ruang Domestik,” J. Peremp. 80, vol. 19, no. 1, pp. 27-52, 2014.

[2] A. Kristijanto, W. Handayani, and P. Anna Levi, "The Effectiveness of Anaerobic Baffled Reactor and Rotating Biological Contactor in Batik Wastewater Treatment," Makara J. Technol., vol. 15, no. 2, p. 168, 2013, doi: 10.7454/mst.v15i2.935.

[3] EU-SWITCH Asia Programme, "Manual for handling of chemical substances: Precautions and first aid," no. 22 Oct 2012, 2011, [Online]. Available: www.cleanbatik.com.

[4] Sulaeman, "Kajian Produksi Bersih Untuk Industri Batik." pp. 23-27, 2005, [Online]. Available: http://ejournal.kemenperin.go.id/dkb/article/view/1109.

[5] I. Nurdalia, "Kajian dan Analisis Peluang Penerapan Produksi Bersih pada Usaha Kecil Batik Cap (Studi Kasus pada Tiga Industri Kecil Batik Cap di Pekalongan)," Progr. Magister Ilmu Lingkung. Progr. Pascasarj., pp. 1-143, 2006.

[6] A. I. R. Handayani, Widhi; Kristijanto, Augustinus IGN and Hunga, "Behind the eco-friendliness of " batik warna alam ," Wacana, vol. 19, no. 1, pp. 235-256, 2018, doi: 10.17510/wacana.v19i1.673.236.

[7] B. Sezen and S. Y. Çankaya, "Effects of Green Manufacturing and Eco-innovation on Sustainability Performance," Procedia - Soc. Behav. Sci., vol. 99, pp. 154-163, 2013, doi: 10.1016/j.sbspro.2013.10.481. 